\title{
〔原著〕
}

\section{未処理フューズドシリカキャピラリー電気泳動による タンパク質の分離}

\section{栗岡 晋*・都丸慶子*・佐藤泰世**・黒須泰行**}

\begin{abstract}
SUMMARY
Separation of 11 model proteins of various $\mathrm{p} I$ and $M W$ values, and proteins in human serum, were performed by capillary electrophoresis using untreated fused silica capillary with $100 \mathrm{~mm}$ sodium borate $(\mathrm{pH} \mathrm{10.0)}$ for electrolyte and $100 \mathrm{~mm}$ phosphoric acid $(\mathrm{pH} 2.5)$ for washing the capillary between the run. Proteins in human serum were also separated into five fractions (albumin, $\alpha_{1}, \alpha_{2}, \beta$ and $\gamma$-globulin) by the same conditions as above within $8 \mathrm{~min}$. The model proteins showed the migration time based on their $\mathrm{p} I$ values and the reproducibility of both the migration times and peak areas was good except for a few basic proteins.
\end{abstract}

Key words : capillary electrophoresis, untreated fused silica, human serum.

はじめに

キャピラリー電気泳動 $(\mathrm{CE})$ 法は, 乙て数年注目を浴 びてきた分析法であり ${ }^{1 \sim 3)}$, 今後, 分析のミクロ化につ れて，ますます期待される分析法の一つである．その特 長は, 試料量が数 $\mathrm{nl}$ または数 $\mathrm{pg}$ である微量分析, 30 分以内の短時間分析，高速液体クロマトグラフィの操作 に似た簡便な操作に要約される．乙の特長を生かした応 用例が，既に数多そ発表されている4 低分子物質に対する分析データが，比較的多いように思 われる. 我々もビタミン $\mathrm{B} 6$ 群の分離条件の検討を行い, その有用性を確認した ${ }^{9)}$. CE 法によって,タンパク質 を分離する際，末処理フューズドシリカキャピラリー内 表面のシラノール基にタンパク質の吸着が生じ, 分離 能，再現性に好ましくない影響を与えることは，広く知 られている事実である。このような影響を避けるため に，キャピラリー内表面の洗浄法の工夫 ${ }^{10)}$, コーティン グ11)，さらに，キャピラリー内へのゲル充填12)などが試
みられている. しかし, 我々は, 未処理フューズドシリ カキャピラリーという素材そのあのを, シンプルに反復 使用するととが，CE 法をよりいっそう簡便化するため に必要であると考えている. 今回, 未処理フューズドシ リカキャピラリーを用いる CE 法によって, 様々な等電 点, 分子量を持つモデルタンパク質群およびヒト血清タ ンパク質の分離分析を試み，それららの移動時間，ピーク 面積の再現性を指標として, 電解液, 添加剂, キャピラ リー洗浄液, キャピラリーの初期化, 試料注入法につい て検討を加えたので，それららの結果について報告する.

\section{材料および方法}

\section{1. モデルタンパク質}

分子量, 等電点を考慮して, Table 1 に示した 11 種 のタンパク質を選択した. 血清アルブミンとリゾチーム はナカライテスクから購入した．他は，シグマ社から購 入した.

Protein analysis by untreated fused silica capillary electrophoresis.

* Susumu Kurioka, Keiko Tomaru; 東京慈恵会医科大学医科学研究所生化学研究部

**, Yasuyo Sato, Yasuyuki Kurosu; 日本分光株式会社技術研究所

Correspondence address : Susumu Kurioka, Division of Biochemistry, Institute of Medical Science, The Jikei University School of Medicine, 3-25-8 Nishi-shinbashi, Minato-ku, Tokyo 105, Japan.

(受付 1992 年 11 月 16 日, 受理 1992 年 12 月 21 日) 
Table 1. List of model proteins.

\begin{tabular}{lrcl}
\hline \multicolumn{1}{c}{ Proteins } & $\mathrm{p} I^{\mathrm{a}}$ & $M W^{\mathrm{b}}$ & Source \\
\hline Trypsin inhibitor & 4.5 & $20 K_{\mathrm{d}}$ & Soybean \\
Ovalbumin & 4.6 & 45 & Chicken \\
Serum albumin & 4.8 & 66 & Bovine \\
Insulin & 5.4 & 6 & Bovine \\
Transferrin & 5.5 & 75 & Human \\
Hemoglobin & 6.9 & 65 & Bovine \\
Myoglobin & 8.1 & 17 & Horse \\
Trypsinogen & 9.3 & 24 & Bovine \\
Ribonuclease A & 9.5 & 14 & Bovine \\
Cytochrome $c$ & 10.1 & 12 & Horse \\
Lysozyme & 11.2 & 14 & Chicken \\
\hline
\end{tabular}

a Isoelectric point. b Molecular weight.

\section{2. ヒト血清}

天然に存在するタンパク質混合法としてヒト血清を選 んだ. ヒト血清は，75 mM 塩化ナトリウムを含む $20 \mathrm{~mm}$ リン酸カリウム緩衝液（pH 7.0）により，5\% 血清濃度 に希釈して用いた。

\section{3. その他の試薬}

試楽は全て特級，又はそれに準ずるあのを使用した. セルバライトは, pH 範囲 3〜10, アンフォラインは, $\mathrm{pH}$ 範囲 4〜6, 及び 9〜11 を購入した.

\section{4. キャピラリー電気泳動の条件}

1) キャピラリー：未妈理フューズドシリカキャピラ リー $(50 \mu \mathrm{m}$ I. D. $\times 50 \mathrm{~cm})$. 有効長は $30 \mathrm{~cm}$.

2) 装置: キャピラリー電気泳動システム CE-800 (日本分光製) を使用 ${ }^{13)}$.

3）電解液 : $100 \mathrm{mM}$ ホウ酸ナトリウム, $30 \mathrm{mM}$ リン 酸ナトリウム，または $100 \mathrm{mM}$ ホウ酸リチウム緩衝液 を所定の $\mathrm{pH}$ に調整して使用.

4）試料注入：サイホン法（落差 $5 \mathrm{~cm}, 10$ 秒）また は電気的移動法 $(2 \mathrm{kV}, 10$ 秒)

5）泳動：12１5 kV (定電圧)，通常 10 分以内.

6）検出：フローセル方式によるオンライン検出（波 長 $200 \mathrm{~nm}$ ).

7） キャピラリー初期化：毎回 5 分間洗浄液を送液， 次に 5 分間電解液を送液。

\section{結 果}

\section{1. 電解液の $\mathrm{pH}$}

等電点がほぼ等しく，分子量が異なるインスリン $\left(M W 6 K_{\mathrm{d}}, \mathrm{p} I 5.4\right)$ とトランスフェリン $\left(M W 75 K_{\mathrm{d}}\right.$, $\mathrm{p} I$ 5.5）を選び，泳動に適した電解液の $\mathrm{pH}$ を検討し た. 電解液は， $\mathrm{pH}$ を $2.0,6.0,7.0$ および 10.0 に調
整した $30 \mathrm{mM}$ リン酸溶液を使用した. その結果を Fig. 1 亿示した. インスリン，トランスフェリンとも， $\mathrm{pH}$ 10.0 の電解液を使用した時の方が， $\mathrm{pH} 2.0$ の電解液よ り，移動時間が短く，シャープなピークとして同定でき た. pH 6.0 および 7.0 では，インスリンのピークがブ ロードになり，トランスフェリンは検出できなかった。

\section{2. 電解液の塩}

$\mathrm{pH} 10.0$ の $100 \mathrm{mM}$ ホウ酸ナトリウム, $100 \mathrm{~mm}$ ホウ 酸リチウム緩衝液，または $30 \mathrm{mM}$ リン酸ナトリウム緩 衝液を電解液として, 10 種類のモデルタンパク質の分離 状況を検討した (Fig. 2)。なお，泳動時の電流值が，10 $\mu \mathrm{A}$ になるように各緩衝液の濃度を調整した. 10 種類の タンパク質の分離は，ホウ酸ナトリウム緩衝液を使用し た時，より再現的に各タンパク質の移動時間に適当な差 が見られ，相互の分離は良好であった。リン酸ナトリウ ム緩衝液を使用した時は, ピークの形状がややシャープ でなかった点と，チトクロム $c$ が, 30 分以内に検出でき なかった点でホウ酸ナトリウム緩衝液より劣っていた。 ホウ酸リチウム緩衝液を使用した時は，各タンパク質の 移動時間の差が小さく，従って相互の分離が悪く，実用 的でないととがわかった. Fig. 3 は，100 mM ホウ酸ナ トリウム（pH 10.0）緩衝液を電解液として泳動した， モデルタンパク質 10 種類の移動時間と等電点および分 子量との関係を図示したあのである.

\section{3. 添加剤}

1, 2 の結果加ら，電解液を $100 \mathrm{mM}$ ホウ酸緩衝液 $(\mathrm{pH}$ 10.0）と決め，さらにとの電解液に添加剂（終濃度各 0.01\%）を加えるととによってモデルタンパク質の移動 時間および分離に与える影響を調べた。

Table 2 に，モデルタンパク質の移動時間に与える添 加剤の影響をまとめて示した. TSAC (trimethyl stearyl ammonium chloride), ポリエチレンイミンの添加 によって，使用したモデルタンパク質の全てが，所定時 間内に検出できなくなった. CHAPS（(3-[(3-cholamidopropyl) dimethylammonio]-1-propanesulfonate), 塩 化コリン，セルバライト（pH 3〜10)，およびアンホラ

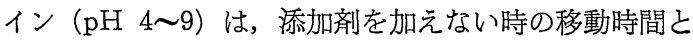
殆ど変わらなかった．アンモニア，リジンの添加は， 移動時間を減少させ，一方，アンホライン（ $\mathrm{pH} \mathrm{4 \sim 9;}$ $\mathrm{pH}$ 11〜12) の添加は，移動時間を明らかに増加させ た. ピーク形状と移動時間の再現性から判断すると, CHAPS，塩化コリン，セルバライト（pH 3〜10）を除 き，今回用いた他の添加剤は，むしろタンパク質の分離 を低下させる傾向が見られた。 

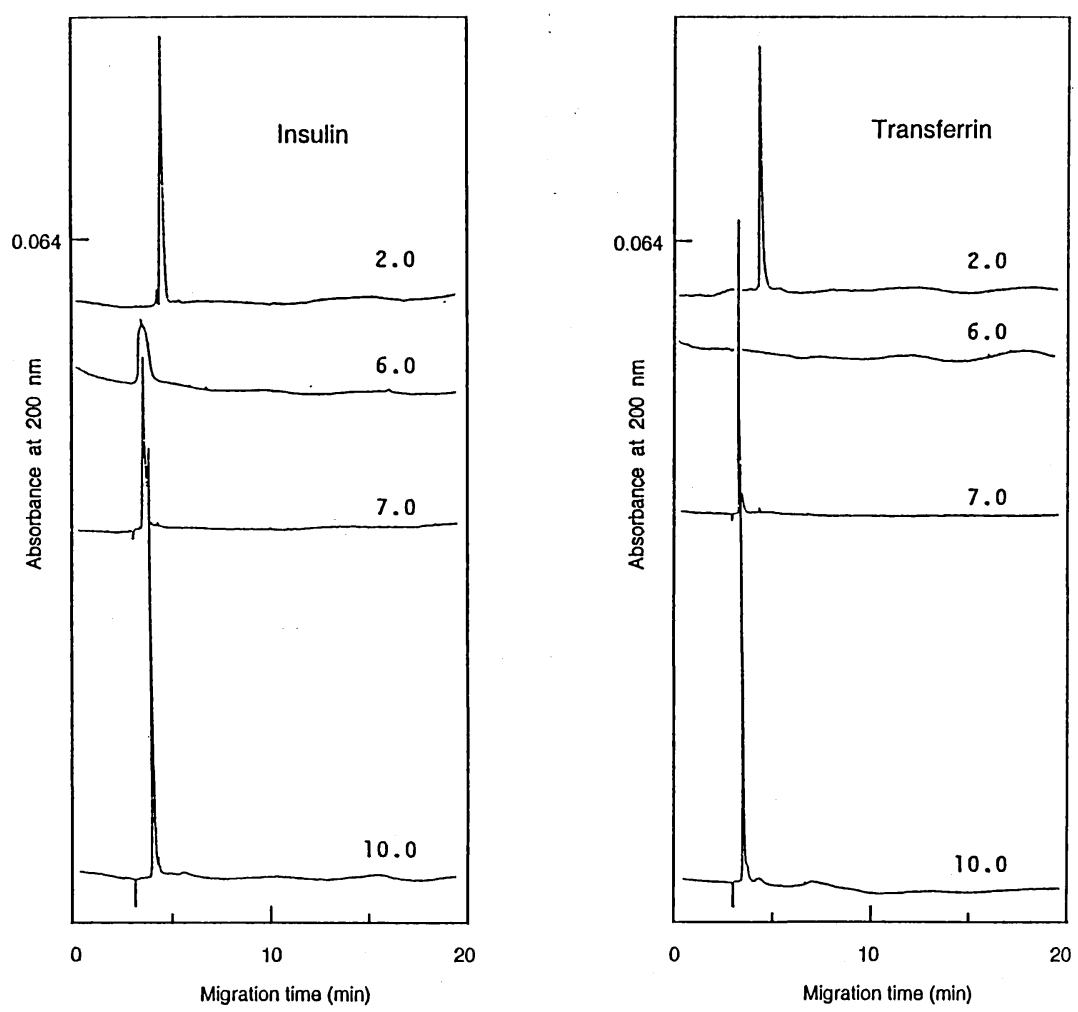

Fig. 1. Electropherogram of insulin and transferrin.

Sample : $1 \mathrm{mg} / \mathrm{ml}$, Injection: siphonic method (height : $5 \mathrm{~cm}$, time: $10 \mathrm{~s}$, Electrolyte : $30 \mathrm{~mm}$ sodium phosphate. Applied voltage : $15 \mathrm{kV}$. Detection : $200 \mathrm{~nm}$.

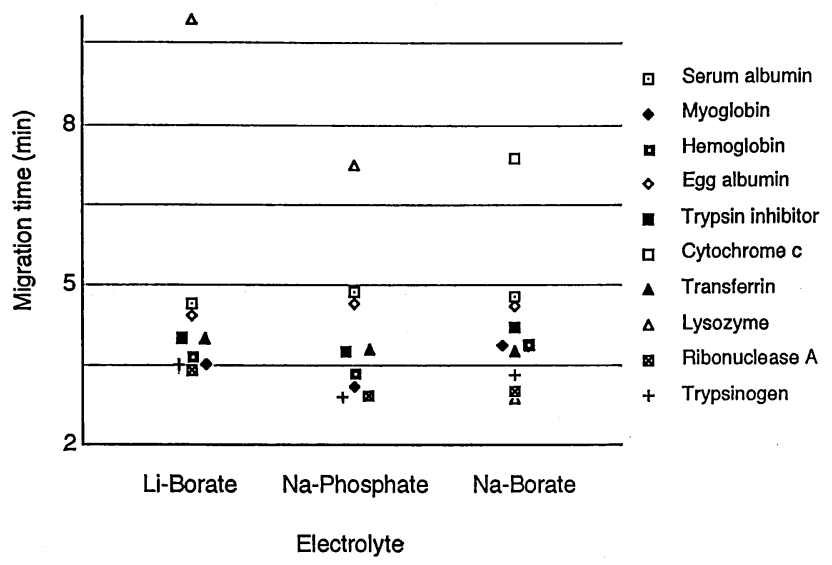

Fig. 2. Migration times of model proteins in three types of electrolyte.

Electrolyte: $100 \mathrm{~mm}$ Li-Borate; $30 \mathrm{~mm}$ Na-Phosphate; $100 \mathrm{~mm}$ NaBorate. $\mathrm{pH}:$ 10.0. Other conditions were as in Fig. 1. 
Table 2. Effect of additives on migration time.

\begin{tabular}{lcccccc}
\hline & \multicolumn{7}{c}{ Proteins $^{\mathrm{a}}$} \\
\cline { 2 - 7 } \multicolumn{1}{c}{ Additives } & 1 & 2 & 3 & 4 & 5 & 6 \\
\hline No additive & 1.00 & 1.00 & 1.00 & 1.00 & 1.00 & 1.00 \\
Ammonia & 0.84 & 0.79 & 0.85 & 0.85 & 0.95 & 0.84 \\
Lysine & 0.87 & 0.82 & 0.88 & 0.86 & 1.00 & 0.85 \\
CHAPS $^{\mathrm{b}}$ & 1.03 & 0.97 & 1.09 & 1.07 & 1.13 & 1.01 \\
Polyethyleneimine & - & - & - & - & - & - \\
TSAC & - & - & - & - & - & - \\
Choline chloride & 0.95 & 0.95 & 0.99 & 1.02 & 1.17 & 0.96 \\
Servalyt (pH 3-10) & 0.97 & 0.93 & 1.07 & 1.05 & 1.21 & 1.00 \\
Ampholine (pH 4-6) & 0.95 & 0.95 & 1.03 & 1.02 & 1.00 & 0.98 \\
Ampholine (pH 9-11) & 1.34 & 1.22 & 1.46 & 1.36 & 1.19 & 1.25 \\
\hline
\end{tabular}

a 1: Serum albumin, 2: Myoglobin, 3: Trypsin inhibitor, 4: Transferrin,

5: Lysozyme, 6: Trypsinogen.

b 3-[(3-Cholamidopropyl) dimethylamino] propanesulfonic acid.

c Trimethyl stearyl ammonium chloride.

- Indicates no detection.

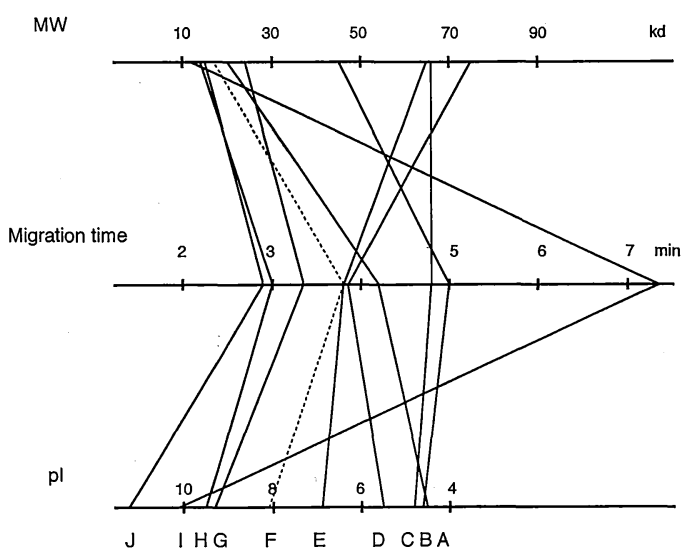

Fig. 3. Migration times vs. $\mathrm{p} I$ and $M W$ of model proteins.

A: Trypsin inhibitor, B: Ovalbumin, C: Serum albumin, D: Transferrin, E: Hemoglobin, F: Myoglobin, G: Trypsinogen, H: Ribonuclease A, I: Cytochrome c, J: Lysozyme.

\section{4. 洗浄液}

$0.1 \mathrm{M}$ 水酸化ナトリウム, $0.1 \mathrm{M}$ 塩酸， $0.01 \sim 0.1 \mathrm{M}$ リン酸緩衝液（ $\mathrm{pH}$ 2.5）をキャピラリー洗浄液として 検討した. キャピラリー初期化後, 6 種類のモデルタン パク質の移動時間，ピーク面積の再現性を比較する方法 により，洗浄液の評価をおこなった（Table 3)．僅かで あるが，リン酸緩衝液が， $0.1 \mathrm{M}$ 水酸化ナトリウムより 移動時間，ピーク面積において良い再現性を示した。 ま た，リン酸緩衝液は，調べた濃度の中では， $0.1 \mathrm{M}$ が最 あ良い再現性を示した．ただ，リゾチームの移動時間の
再現性は, リン酸緩衝液の濃度によって変化する傾向が あった． $0.1 \mathrm{M}$ 塩酸は，ピーク面積の再現性から，十分 な洗浄効果がないと判断した。

\section{5. 試料注入法}

サイホン法または電気的移動法によって試料注入をお こない，モデルタンパク質またはヒト血清タンパク質各 分画の移動時間，ピーク面積の再現性について調べた. Table 4 は，ヒト血清タンパク質各分画（アルブミン，

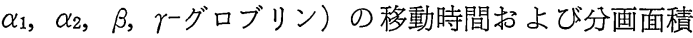
の再現性を，注入法別に調へ，\% CV で示した結果であ る. 電気的移動法の方が，わずかに再現性の良いととを 示している. データの表示はしていないが，モデルタン パク質についてあ同様の傾向が得られた：それぞれの試 料注入法によって得られたヒト血清タンパク質各分画の ピーク面積比（\%）を Table 5 に示した. 電気的移動 法による注入では, 移動時間の長いアルブミン分画の比 が見かけ上減少，逆に移動時間の短い $\gamma$-グロブリン分 画の比が，見かけ上増加している．Fig. 4 は，健常人な らびに M-proteinemia の血清タンパク質のエレクトロ フェログラムであり, 試料注入法による違いが, よく理 解できる.

\section{考察}

未処理フューズドキャピラリーを使用して CE によ るタンパク質の分離分析を検討した結果, 電解液として

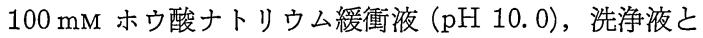
して $0.1 \mathrm{M}$ リン酸緩衝液 $(\mathrm{pH}$ 2.5) を用い，泳動ごとに 洗浄液と電解液を一定量ずつ送液して，キャピラリー初 
Table 3. Effect of washing solutions on reproducibility of migration time and peak area.

Migration time (\% CV)

\begin{tabular}{lcccccc}
\hline & \multicolumn{7}{c}{ Proteins } \\
\cline { 2 - 7 } \multicolumn{1}{c}{ Washing solutions } & 1 & 2 & 3 & \multicolumn{1}{c}{4} & \multicolumn{1}{c}{5} & \multicolumn{1}{c}{6} \\
\hline $0.01 \mathrm{M}$ phosphate buffer & 0.60 & 3.78 & 3.74 & 0.53 & 8.80 & 1.15 \\
$0.1 \mathrm{M} \mathrm{phosphate} \mathrm{buffer}$ & 0.68 & 1.40 & 0.87 & 1.14 & 3.03 & 0.60 \\
$0.2 \mathrm{M} \mathrm{phosphate} \mathrm{buffer}$ & 0.92 & 0.12 & 2.39 & 0.17 & 10.49 & 1.81 \\
$0.1 \mathrm{M} \mathrm{NaOH}$ & 5.51 & 1.33 & 1.11 & 0.50 & 2.01 & 0.95 \\
$0.1 \mathrm{M} \mathrm{HCl}$ & 2.27 & 1.28 & 3.06 & 1.29 & 2.50 & 0.49 \\
\hline & & & & & \multicolumn{3}{c}{$(n=8-10)$}
\end{tabular}

Peak area (\% CV)

\begin{tabular}{lrrrrrr}
\hline & \multicolumn{6}{c}{ Proteins } \\
\cline { 2 - 7 } \multicolumn{1}{c}{ Washing solutions } & \multicolumn{1}{c}{1} & \multicolumn{1}{c}{2} & \multicolumn{1}{c}{3} & \multicolumn{1}{c}{4} & \multicolumn{1}{c}{5} \\
\hline $0.01 \mathrm{M}$ phosphate buffer & 9.95 & 12.26 & 13.75 & 8.63 & 9.69 & 9.36 \\
$0.1 \mathrm{M}$ phosphate buffer & 8.19 & 6.97 & 6.50 & 6.37 & 8.22 & 8.89 \\
$0.2 \mathrm{M} \mathrm{phosphate} \mathrm{buffer}$ & 12.02 & 10.33 & 11.15 & 11.22 & 13.41 & 15.79 \\
$0.1 \mathrm{M} \mathrm{NaOH}$ & 12.76 & 21.32 & 13.96 & 7.88 & 10.39 & 13.93 \\
$0.1 \mathrm{M} \mathrm{HCl}$ & 16.77 & 14.59 & 16.21 & 14.05 & 16.08 & 17.12 \\
\hline
\end{tabular}

1: Serum albumin, 2: Myoglobin, 3: Trypsin inhibitor, 4: Transferrin,

5: Lysozyme, 6: Trypsinogen.

Table 4. Effects of injection methods on reproducibility of migration time and peak area of serum* protein fractions.

Migration time (\% CV)

\begin{tabular}{lccccc}
\hline & \multicolumn{5}{c}{ Fractions } \\
\cline { 2 - 6 } Methods & Albumin & $\alpha_{1}$ & $\alpha_{2}$ & $\beta$ & $\gamma$ \\
\hline Siphonic & 2.34 & 2.29 & 2.19 & 2.05 & 2.02 \\
Electrophoretic & 1.07 & 1.29 & 1.31 & 1.22 & 1.40 \\
\hline & & \multicolumn{5}{c}{$(n=12-16)$}
\end{tabular}

Peak area $(\% \mathrm{CV})$

\begin{tabular}{lccccc}
\hline & \multicolumn{5}{c}{ Fractions } \\
\cline { 2 - 6 } \multicolumn{1}{c}{ Methods } & Albumin & $\alpha_{1}$ & $\alpha_{2}$ & $\beta$ & $\gamma$ \\
\hline Siphonic & 1.99 & 15.66 & 8.93 & 7.77 & 5.19 \\
Electrophoretic & 1.50 & 17.44 & 3.87 & 3.89 & 3.63 \\
\hline \multirow{2}{*}{ * Normal human serum. } & & \multicolumn{4}{c}{$(n=12-16)$}
\end{tabular}

期化を行うことが，再現性ある分離分析に有効であると とがわかった.

$\mathrm{pH} 10.0$ でのタンパク質の移動時間を決める基本的 な要素は, 電気浸透流とタンパク質の実効電荷であると 考えられる. Fig. 3 亿示すように，ホウ酸ナトリウム電 解液中で観察された各モデルタンパク質の移動時間は，
Table 5. Percent ratio of serum protein fractions and their apparent changes by injection methods.

\begin{tabular}{lccccc}
\hline & \multicolumn{5}{c}{ Fractions } \\
\cline { 2 - 6 } \multicolumn{1}{c}{ Methods } & Albumin & $\alpha_{1}$ & $\alpha_{2}$ & \multicolumn{1}{c}{$\beta$} & $\gamma$ \\
\hline Siphonic & 65.8 & 4.4 & 7.9 & 8.9 & 12.9 \\
Electrophoretic & 56.7 & 3.5 & 9.7 & 10.9 & 19.2 \\
\hline & & & & $(n=16)$
\end{tabular}

チトクロム $c$ を除いて，ほぼ等電点と相関していた。ま た，等電点がほぼ同じであるタンパク質（血清アルブミ ン, オボアルブミン, トリプシンインヒビター）の挙動 は, 分子量の違いによって移動時間の予測を行える可能 性を示唆していた ${ }^{14)}$. ミオグロビン，へモグロビン，ト ランスフェリンは，等電点に差があるが，それぞれの移 動時間はほぼ同じであった. チトクロムcの長い移動時 間は, 解離したシラノール基とチトクロム $c$ との静電気 的相互作用によるあのと考えられる. 同じことは, リン 酸ナトリウム（pH 10.0）を電解液として使用した時に 見られ，乙の時, リゾチームの移動時間む大幅に増加し た (Fig. 2). 今回, 設定した泳動条件では, 塩基性夕 ンパク質の分離に問題点があり，また，タンパク質の移 動時間が, 等電点以外に, 分子量やメタル $(\mathrm{Fe})$ の含有 
(a) Siphonic method

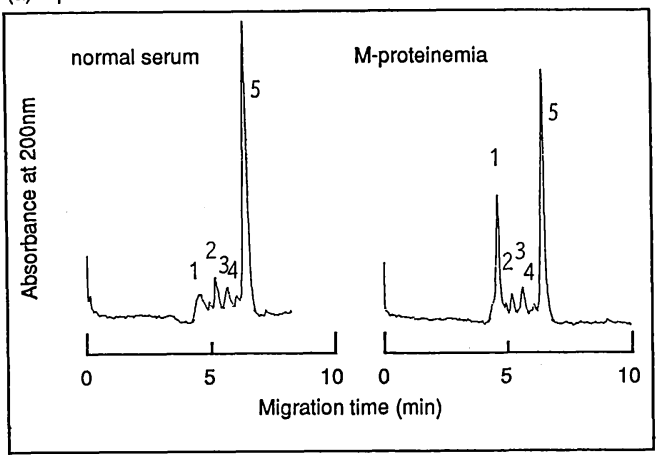

(b) Electrophoretic method

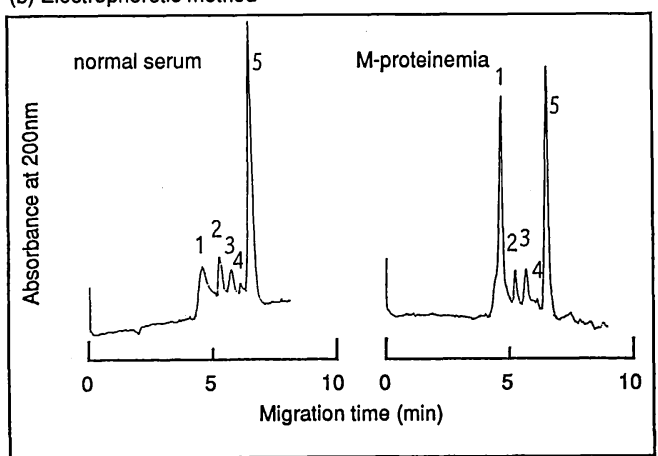

Fig. 4. Electropherograms of human serum using different injection methods.

(a) siphonic method (height: $5 \mathrm{~cm}$, time: $10 \mathrm{~s}$ ). (b) electrophoretic method $(2 \mathrm{kV}, 10 \mathrm{~s})$. Electrolyte: $100 \mathrm{~mm}$ Na-borate ( $\mathrm{pH} 10.0)$. Other conditions were as in Fig. $1.1: \gamma$-Globulin, $2: \beta$-Globulin, $3: \alpha_{2}$-Globulin, $4: \alpha_{1}$-Globulin, $5:$ Albumin.

によって影響されているととが示唆された．電解質の塩 を検討した中で，リチウム塩は，ナトリウム塩よりタン パク質の溶解力が大きいととから, リチウムイオンを含 む電解液に，より良好な分離を期待したが，Fig. 2 に示 したような結果はむしろ逆であった.タンパク質とシラ ノール基の相互作用を抑える手段として, $\mathrm{pH} 10.0$ の 電解液を選択してきたが，塩基性タンパク質の大きな移 動時間は (Fig. 2，3), 依然としてての相互作用がある ことを示している．そこで，乙の相互作用に拮抗できる 物質を電解液に加えるととによって，分離改善の可能性 を検討した。しかし，今回試みた範囲内では，分離能， 再現性を改善できるような添加剤を見いだせなかった。

未処理フューズドキャピラリーを反復使用するため に，再現性の高いキャピラリー初期化が必須であり，泳 動後のキャピラリー洗浄が重要である. 従来, 洗浄法之
して水酸化ナトリウム水溶液が多用されているけれど あ，Zhu ら ${ }^{102}$ はへモグロビンを使用し，分光学的方法に よって, リン酸水溶液による洗浄の有用性を報告してい る. 最近, Lee ら ${ }^{15)}$ は, $1 \mathrm{M} \mathrm{NaOH}$ が洗浄液として優 れているてとを報告している，我々は，モデルタンパク 質,ならびにヒト血清タンパク質を使用して, 移動時 間, ピーク面積の再現性から, 洗浄液の効果を検定した

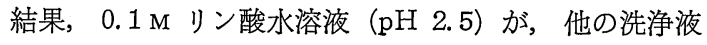
と比較して有用であるてとを確認した.

$\mathrm{CE}$ 法の試料注入法にはサイホン法, 電気的移動法, 加圧・吸引法がある。サイホン法は注入が簡便である が, 注入量の再現性に若干問題点があるとされている. 電気的移動法は注入量の再現性はあるが，多成分を含む 陚料の場合，原理的に各成分を均等に注入するととが できない，加圧・吸引法は簡便であるが，緘細な制御が 困難である. 今回, サイホン法之電気的移動法を検討し た. 血清中のタンパク質をアルブミン, $\alpha_{1}, \alpha_{2}, \beta, \gamma-ク ゙$ ロブリン各分画の面積比 (\%)として算出した場合, 各成 分を均等に注入できない電気的移動法の特長が，よく反 映されていた (Table 5, Fig. 4). 血清タンパク質の各 分画の比を問題とする時, 電気的移動法によって得られ た比を補正するととは原理的には可能と思われる.ただ し，一般的に，試料中に移動度の差が大きい二つの物質 が存在した場合, 通常の注入条件 (数 $\mathrm{kV}$, 数秒) の範 囲では移動度の小さい物質の注入が著しく不利になった り，また同じ成分比であっても，全体の濃度や希釈液の 塩濃度の影響を受けてしまうため, 補正が極めて困難で ある. 一方，サイホン法は，エレクトロフェログラムか ら, 直接, 比が読み取れる簡便性があるように思われる.

未処理フューズドシリカキャピラリーを用いた CE 法 は，今後，改善すべき点はあるけれどあ，微量，高分 離, 迅速性, 簡便性から, タンパク質の分離分析の有用 な手法であるととを確認するととができた.

\section{文献}

1) Karger BL, Cohen AS, Guttman A. Highperformance capillary electrophoresis in the biological sciences. J Chromatogr 1989; 492 : 585-614.

2) Mikkers FEP, Everaerts FM, Verheggen Th PEM. High-performance zone electrophoresis. J Chromatogr 1979; 169 : 11-20.

3) Jorgenson JW, Lukacs KD. Zone electrophoresis in open-tubular glass capillaries. Anal Chem $1981 ; 53: 1298-302$.

4) Chen FTA, Liu CM, Hsieh YZ, Sternberg 
JC. Capillary electrophoresis-a new clinical tool. Clin Chem $1991 ; 37: 14-9$.

5) Nielsen RG, Sittampalam GS, Rickard EC. Capillary zone electrophoresis of insulin and growth hormone. Anal Biochem 1989; $177: 20$ 6.

6) Hogan BL, Yeung ES. Indirect fluorometric detection of tryptic digests separated by capillary zone electrophoresis. J Chromatogr Sci $1990 ; 28: 15-8$.

7) Cheng YF, Dovichi NJ. Subattomole amino acid analysis by capillary zone electrophoresis and laser-induced fluorescence. Science 1988; $242: 562-4$.

8) Takeuchi T, Yeung ES. High-performance liquid chromatographic separation of inorganic anions on a silica gel column modified with a quaternary ammonium salt. J Chromatogr $1986 ; 370: 83-92$.

9）黑須泰行, 佐藤泰世, 宇田川慶子, 栗岡 晋. キ ヤピラリ一電気泳動によるビタミン $\mathrm{B}_{6}$ 群の分析 に関する基礎的研究. ビタミン 1992；66：91100.

10) Zhu $M$, Rodrigues $R$, Hansen $D$, Wehr $T$. Capillary electrophoresis of proteins under alkaline conditions. J Chromatogr 1990; 516 : $123-31$.

11) Towns JK, Regnier FE. Polyethyleneiminebonded phases in the separation of proteins by capillary electrophoresis. J Chromatogr 1990 ; 516: 69-78.

12) Cohen AS, Karger BL. High-performance sodium dodecyl sulfate polyacrylamide gel capillary electrophoresis of peptides and proteins. J Chromatogr 1987 ; 397 : 409-17.
13) Kurosu $Y$, Hibi K, Sasaki T, Saito M. Influence of temperature control in capillary electrophoresis. J High Resolut Chromatogr 1991; $14: 200-3$.

14) Kurosu $Y$, Sato $Y$, Senda M. Investigation of migration behaviors of peptides and proteins by capillary zone electrophoresis. Anal Sci $1991 ; 7: 273-6$.

15) Lee KG, Heo GS. Free solution capillary electrophoresis of proteins using untreated fusedsilica capillaries. J Chromatogr 1991; 559 : 317-24.

\section{要 旨}

未処理フューズドシリカキャピラリーを用いたキャピ ラリー電気泳動法によって, 11 種のモデルタンパク質 ( $M W$ 6 75K $K_{\mathrm{d}}: \mathrm{p} I$ 4.5 11.2) 及びヒト血清タンパク 質の分離分析を試みた。電解液, 添加剂, キャピラリー 洗浄法, 試料注入法について, タンパク質の移動時間, ピーク面積の再現性を指標として検討した。電解液とし て $100 \mathrm{mM}$ ホウ酸ナトリウム $(\mathrm{pH} \mathrm{10.0)}$, 洗浄液として $0.1 \mathrm{M}$ リン酸水溶液 $(\mathrm{pH} 2.5)$, 泳動ごとに洗浄液と電 解液を交互に 5 分間送液してキャピラリーの初期化を行 い，再現性の良い分離分析が達成できた。使用したモデ ルタンパク質は，チトクロム $c$ を除き，等電点と相関す る移動時間を示した. ヒト血清タンパク質は, 8 分以内 で分離分析が可能であった，さらに改善すべき点はある が，未処理フューズドシリカキャピラリーを用いた電気 泳動法は, 微量, 高分離, 迅速, 簡便なタンパク質分析 手法として有用であることを確認した。 